\title{
Mysl a tělo humanistického buddhismu v praxi: Př́padová studie chrámu a komunity Fo Guang Shan ve Vídni
}

\author{
MARTIN ŠPIRK*
}

Tento text je koncipován jako případová studie komunity sdružené kolem vídeňského chrámu řádu Fo Guang Shan (Fó guāng shān ${ }^{1}$ dále jako FGS), se kterým jsem se poprvé setkal před osmi lety při cestách po Novém Zélandu. Již tenkrát moji pozornost upoutaly specifické charakteristiky hnutí, mezi něž patří globalizační tendence, akcentování konceptu humanistického buddhismu nebo vstřícný postoj k ordinaci a uplatnění žen v sangze. ${ }^{2}$ Později jsem zjistil, že chrámy FGS stojí i v Evropě, a rozhodl jsem se v jedné z evropských lokalit provést výzkum a porozumět konceptu humanistického buddhismu a jeho vztahu k misijní činnosti řádu. Vedle toho se v tomto textu věnuji otázkám, jakou roli hraje náboženská materiální kultura v životě evropského ,západního“ buddhisty a jak je či není jeho žité náboženství ovlivněno sebe-prezentačními strategiemi buddhistických řádů, které na Západ expandují.

* Vznik této studie byl podpořen projektem ,Výzkumné trendy v současné religionistice“ (MUNI/A/0858/2019), řešeným Ústavem religionistiky FF MU v roce 2020. Terénní výzkum, z něhož tato studie vychází, byl podpořen grantem CEEPUS.

1 Při transkripci čínských jmen a termínů se držím anglických přepisů tak, jak je použivá řád FGS ve svých publikacích. U prvního výskytu jména uvádím v závorce přepis v pinyinu. U zavedených čínských termínů používám český př̌epis, v závorce opět pinyin.

2 Sanghu FGS tvoří 90 \% žen, na samotném Tchaj-wanu jsou chrámy obývány vesměs pouze mniškami. Ty v některých lokalitách sdílejí prostor s mnichy a společně participují na denních aktivitách (což je např. pro théravádinskou sanghu Srí Lanky nebo Thajska nemyslitelné). Více viz Yu-Shuang Yao - Richard Gombrich, „Christianity as Model and Analogue in the Formation of the ,Humanistic 'Buddhism of Tài Xū and Hsīng Yún“, Buddhist Studies Review 34/2, 2017, 205-237: 216, 225. 


\section{Nástroje bádání: Diskurzivní analýza a výzkum náboženské materiální kultury}

Můj zájem o mocenský aspekt sebe-prezentačních strategií FGS se postupně formoval během delšího období přípravy na terénní výzkum, především v době, kdy jsem se seznamoval s propagačními materiály řádu. Po prvních návštěvách konkrétních lokalit (především v Christchurch a následně ve Vídni) a předběžných analýzách materiálů mi chrámy FGS začaly stále více připomínat galerie nebo muzea. Inspirativním přístupem pro analýzu dat se mi pak stala upravená diskurzivní analýza. ${ }^{3}$ Ta se zaměřuje na instituce, které skrze produkci vizuálních materiálů šíři vědění, jež je provázané s možností ovládat a kontrolovat. Na základě analýzy předpisů, architektury, kaligrafií na stěnách, vyvěšených panelů či propagačních materiálů, organizace prostoru a diskurzů, které jsou skrze zmíněné fenomény artikulovány, se snažím identifikovat, jaké formy znalostí převážně konstituují tuto instituci - tzv. instituční aparát. $\mathrm{K}$ tomu patří také analýza využívaných technologií (technik), které jsou tímto aparátem vytvářeny a mají funkci uvést „moc“ do praxe. ${ }^{4}$ Ve zkratce je cílem analýzy nalézt specifické projevy a účinky, kterými instituce působí na pozorující návštěvníky, a tvaruje tak jejich zkušenosti, pocity, ale např́íklad i politické soudy. Institucionální technologie nebývají explicitně formulovány v samotných diskurzech, jedná se o rozptýlený soubor nástrojů a metod, který společně s institucionálním aparátem vytváří „mikro-fyziku“ mocenské strategie. ${ }^{5}$ Zájem o pochopení těchto mocenských uspořádání a strategií a snaha o identifikaci tzv. mysli a těla instituce ${ }^{6}$ mi pak dopomohly klást si otázky typu: Jaké myšlenky jsou návštěvníkům chrámu

3 Tuto tzv. diskurzivní analýzu I a II zevrubně popsala Gillian Rose ve své knize Visual Methodologies. Zatímco diskurzivní analýza I cílí více na hledání způsobu, jakým obrazy a vizuální materiály konstruují úvahy o sociálním světě, a hledá strategie přesvědčivosti, diskurzivní analýza II se více zajímá o materiální praktiky institucí, dívá se na místa vystavování. V této studii je aplikována na instituci chrámu, zatímco Rose používá diskurzivní analýzu II převážně pro instituce typu muzea nebo galerie. Více viz Gillian Rose, Visual Methodologies: An Introduction to Researching with Visual Materials, London: Sage ${ }^{4} 2016$ (1. vyd. 2001), 186-252.

4 G. Rose, Visual Methodologies..., 223.

5 Michel Foucault, Discipline and Punish: The Birth of the Prison, trans. Alan Sheridan, New York: Vintage Books 1977, 26.

$6 \mathrm{~S}$ pojmy „mysl“ a „tělo“ pracuji v tomto textu analogicky k Foucaultovým termínům „,aparát“ a „technologie“ instituce. Jak píše Rose, aparát je někdy velmi těžko odlišitelný od technologií (viz G. Rose, Visual Methodologies..., 223), stejně jako jsou dle mého názoru propojeny mysl a tělo (pro rozbor psychofyzického problému a jeho historického ukotvení z pohledu antropologie a výzkumu náboženství viz např. Jojada Verrips, „Body and Mind: Material for Never-Ending Intellectual Odyssey“, in: id. [ed.], Religion and Material Culture: The Matter of Belief, London - New York: Routledge 2010, 21-39). 
vštěpovány, jaké vizuální a textové prostředky jsou k tomu využívány, jak je návštěvník prostorem veden a kontrolován?

Pro studium žitého náboženství komunity jsem se inspiroval výzkumným proudem, který se zaměřuje na náboženskou materiální kulturu. Tento přístup pracuje především s prostorem, artefakty, oblečením, rituály a ceremoniemi, stejně jako s vnímáním a pocity participantů, které souvisí s jejich každodenním náboženským životem. Dochází tedy $\mathrm{k}$ posunu pozornosti badatele od věr a nauk k náboženské praxi, od idejí, přesvědčení a textů $\mathrm{k}$ věcem, tělu a emocím. ${ }^{7}$ Základním východiskem tohoto přístupu je teze, že tělo, mysl a věci, které nás obklopují, jsou vzájemně provázané a nelze je ve spletité sociální interakci od sebe jasně oddělit. Nejde tedy pouze o studium objektů a míst; prožívání a vnímání, performance a praxe, čas a akce tvoři dynamiku studia materiální kultury. ${ }^{8}$

Tato teoretická východiska se odrazila také v designu výzkumných rozhovorů, v jejichž úvodní narativní části mí komunikační partneři vyprávěli o tom, jak se stali buddhisty, kdy přišli do kontaktu s hnutím FGS, jakou hraje řád roli v jejich životech a jaký mají názor na vývoj komunity. V následných otázkách jsem se pak zaměřil na již zmíněné kategorie: 1) prožité emoce a pocity vzhledem ke komunitě a chrámu, 2) věci a artefakty, které jsou participantům výzkumu blízké, 3) náboženský prostor, jak soukromý, tak související s FGS a případně i dalšími organizacemi ve Vídni. Otázky směřovaly taktéž k 4) rituálům a souvisejícím činnostem, opět jak soukromým, tak veřejným.

Skrze etnografickou práci v terénu jsem hledal odpověd’ na to, jaké prostředky a mechanismy využívá vídeňský chrám/komunita k navazování kontaktu s potencionálními zájemci o FGS, jaké je složení místní sanghy, kolik je zde členů s jiným než čínským kulturně-sociálním zázemím a jak pracují tito lidé se stávající náboženskou kulturou vídeňské FGS. Taktéž mne zajímalo, jak reflektují „západní“ členové organizaci řádu, jeho vnitřní mocenské struktury a sebe-prezentační strategie.

7 Teoretický základ a inspirace je čerpána především ze sborníku David Morgan (ed.), Religion and Material Culture: The Matter of Belief, London - New York: Routledge 2010, a z odborného periodika Material Religion: The Journal of Objects, Art and Belief (základním „manifestem“ tohoto časopisu je text Birgit Meyer - David Morgan - Crispin Paine et al., „The Origin and Mission of Material Religion“, Religion 40, 2010, 207-211).

8 David Morgan, „Materiality, Social Analysis, and the Study of Religion“, in: id. (ed.), Religion and Material Culture: The Matter of Belief, London - New York: Routledge 2010, 55-74: 68-73. 


\section{Terénní výzkum}

Ve vídeňském chrámu FGS jsem strávil jeden měsíc. ${ }^{9} \mathrm{~V}$ době mého pobytu zde sloužila jedna mniška a při ceremoniích se pohybovalo okolo sta věřících. Hlavními zdroji dat mi byly vlastní fotografie a terénní poznámky, pořizované při každodenních zúčastněných pozorováních a rozhovorech, přepisy nahrávek interview s členy místní sanghy (mniškou a těmi, kteři pocházeli z jiného kulturně-sociálního zázemí než samotný řád) a množství textových a „materiálních“ pramenů. Mezi tyto prameny řadím nejen propagační materiály - knihy, plakáty, panely nebo webové stránky FGS Vídeň, ale také např́íklad architekturu, způsob organizace prostoru budovy nebo technické vybavení interiéru.

Ve všedních dnech jsem se pohyboval v prostorách chrámu a sbíral vizuální a textové materiály, a to pod stálým dohledem představené mnišky a některých laiků, kteří měli daný den službu (vždy šlo o ženy důchodového věku, jež v chrámu uklízely a vypomáhaly mnišce). Během měsíce jsem systematicky prošel celou místní knihovnu (zajímala mě především literatura FGS vydávaná v jiných jazycích, než je čínština) a čtyři patra interiéru, která jsem nafotil a detailně popsal v terénních poznámkách. Po budově jsem měl vesměs neomezený pohyb, některé místnosti ale byly uzamčené a ke vstupu bylo třeba povolení. ${ }^{10}$ Při nedělních ceremoniích a speciálních svátcích jsem se plně účastnil rituálů (a občas mohl i fotografovat), později jsem byl zván i na společnou hostinu, která následovala po každé podobné akci. Představená mniška mě ujistila, že informovala místní členy FGS o mém výzkumu a jeho záměrech (ona s nimi byla seznámena již půl roku před samotným výzkumem, kdy jsem lokalitu navštívil). „Západní“ členy sanghy jsem oslovil bud' sám během pobytu, anebo mi rozhovory domluvila místní mniška. Komunikace probíhala většinou v angličtině či němčině, interview dohromady obsáhla okolo dvanácti hodin a účastnili se jich (jednotlivě) všichni „západní“ členové sanghy FGS Vídeň (Hans, Ernst a Friedrich). ${ }^{11} \mathrm{~S}$ představenou mniškou chrámu proběhly dohromady rozhovory tři, z toho jeden byl nahráván a další dva jsou zachycené v terénních poznámkách.

Během výzkumu jsem si zaznamenával vlastní pocity a prožitky, jak při rozhovorech s místními členy, tak v průběhu ceremonií, kterých jsem se aktivně zúčastnil. Nedílnou složkou celé práce a bádání je tedy moje vlast-

9 Výzkum proběhl mezi 2. 11. 2017 a 30. 11. 2017 a byl mi umožněn díky programu CEEPUS ve spolupráci s Vídeňskou univerzitou (Universität Wien).

10 Objekt chrámu byl přistupný denně kromě pondělí od 10 do přibližně 17 hodin, kdy se budova zamykala.

11 Jména participantů byla v souladu s informovaným souhlasem pozměněna či vypuštěna. 
ní reflexivita. Vědec, který vstupuje do terénu, není nikdy vůči předmětu zkoumání nezúčastněným pozorovatelem, bude vždy také součástí terénní situace. Domnívám se, že částečná personalizace analýz a výstupů proto není na škodu, naopak poukazuje na to, že tento rozměr bádání nebyl opomenut. ${ }^{12}$ Při samotném sběru a analýze vizuálních materiálů a textů se stává reflexivita taktéž neoddělitelným prvkem - i výzkumník se řadí mezi diváky/čtenáře a je spoluaktérem ve hře sebe-prezentačních strategií, které jsou v místě výzkumu uplatňovány.

\section{Humanistický buddhismus a jeho interpretace v podání FGS, misijní činnost řádu}

Fo Guang Shan je jedním z nejrozšířenějších a nejlépe organizovaných buddhistických řádů na světě. ${ }^{13}$ Řád vznikl na Tchaj-wanu, kde čínský mnich Hsing Yun (Xīng Yún) založil roku 1967 první chrám FGS. Od té doby FGS nepřetržitě expanduje, podařilo se mu vybudovat velmi rozsáhlou sít chrámů a dalších ,buněk“ mnišské/laické organizace BLIA (Buddha's Light International Association), ${ }^{14}$ která byla založena roku 1992. ${ }^{15}$ Dle oficiálních zdrojů má FGS přes 200 chrámů a center - 38 se jich nachází v Asii (mimo Č́nu), 11 v Austrálii a na Novém Zélandu, 42 v Americe, 8 v Africe a 14 v Evropě. ${ }^{16}$

I když se FGS ve svém učení a praxi hlásí k čínské čchanové tradici, zakladatel Hsing Yun mluví o škole „humanistického buddhismu“. Doktrína humanistického buddhismu je podle textů, které řád vydává, charakteristická například důrazem na každodenní život a přítomný okamžik, altruismus či universalismus. ${ }^{17}$ Především ale má jít o obrat od

12 Obdobně se k tomuto problému staví např. Martin Soukup, Terénní výzkum v sociální a kulturni antropologii, Praha: Karolinum 2014, 127-131.

13 Organizace se objevila v 50. letech 20. století a nejprve fungovala jako vydavatelství. Do širšího povědomí na Tchaj-wanu se dostala až v 80. letech po skončení stanného práva (1949-1987) a největší expanzi prodělala v 90. letech 20. století. Více viz Jonathan Mair, „Fo Guang Shan Buddhism and Ethical Conversations across Borders: ,Sowing Seeds of Affinity“" [online], Collegium: Studies across Disciplines in the Humanities and Social Sciences 15, 2014, <https://helda.helsinki.fi/bitstream/handle/10138/45244/04_MAIR_1305.pdf?sequence=1>, [24. 8. 2019].

14 BLIA je globální nevládní nezisková organizace, složená z mnišek/mnichů i laiček/ laiků. Uznává hodnoty humanistického buddhismu a cílí na sociální pokrok. Hlavní sídlo organizace se nachází v Kalifornii (Hacienda Heights). Více viz webové stránky organizace, <http://www.bliango.org/>, [21. 9. 2020].

15 Stuart Chandler, „Globalizing Chinese Culture, Localizing Buddhist Teachings: The Internationalization of Foguangshan“, Journal of Global Buddhism 3, 2002, 46-78: 52.

16 Viz Fo Guang Shan Monastery Worldwide Web [online], <https://www.fgs.org.tw/en/ worldwide/Index/>, [11. 9. 2020].

17 Yifa, The Tender Heart, New York: Lantern Books 2007, 118-119. 
izolace, uzavřených klášterů a „sebestředného individualismu“ k vnějšímu světu - charitativní a misijní činnosti a humanistickým ideálům. ${ }^{18}$

Podobný koncept, v originále „rensheng Fojiao“ (rén shēng Fójiào), později „renjian Fojiao“ (rén jiān Fójiào), ${ }^{19}$ však poprvé nepoužil Hsing Yun, ale mnich Taixu (Tàixü), který se stavěl proti tehdejšímu zaměření čínského buddhismu na pohřební obřady a rituály, které přesouvaly vzniklé zásluhy do budoucích životů. Místo toho navrhoval, aby buddhisté obětovali svůj čas a energii pro živé a aby praxe souvisela i s aktivní participací ve společnosti. Taixu (1890-1947) se ve své činnosti nechal inspirovat strategiemi a technikami, které využívaly křestanské organizace. Za účelem domácí propagandy vydával vlastní magazín (tehdy velmi moderní mediální formát), v němž dělal reklamu svým kurzům a publikacím, taktéž pořádal konference a hojně vyučoval. Ve svých projevech vyzdvihoval témata, jako jsou harmonie mezi buddhismem a modernitou, redukce a hledání esence mahájánového buddhismu, klášterní reformy či progresivní buddhistické vzdělání a sociální práce. Byl přesvědčen, že pro buddhismus esenciální altruistické motivy jsou univerzální a aplikovatelné i na Západě a že se díky nim dokáže „harmonicky“ vypořádat s ideologickými rivaly - západní vědou, filozofií, ale i socialismem. Položil tak intelektuální základy humanistického buddhismu: misijního úsilí, které mělo za cíl skrze globální šíření buddhismu zmírnit utrpení světa. ${ }^{20}$ Taixu sice nesympatizoval s křestanskou teologií (naopak, často ji ve svých pracích kritizoval), zajímala ho však křestanská misijní praxe. Během svých cest po Evropě obdivoval tamější moderní společnost a souhlasně kvitoval především organizační schopnosti Evropanů, jejichž základy spatřoval $\mathrm{v}$ šîření křestanství během středověku. Myšlenka víry $\mathrm{v}$ jednoho boha spojila dle Taixu Evropu i v činech skrze řád, dekorum a společné rituá-

18 Man Chien, Entry into the Profound: A First Step to Understanding Buddhism, Berkeley: International Buddhist Association of Australia 2000, 40-41.

19 Termín rensheng Fojiao je složen ze slov „lidská bytost““ (rensheng) a „učení Buddhy“ (Fojiao). Odkazuje k myšlence, že jako lidské bytosti jsme dle buddhistické nauky v nejlepší pozici pro rozvoj moudrosti a vytváření pozitivních skutků tak, abychom dosáhli probuzení. Později došlo k transformaci pojmu na renjian („lidská říše“) Fojiao, kde je ještě více akcentována aktivní participace buddhismu ve společnosti. Dle Bingenheimera používal Taixu oba termíny pro popis stejného fenoménu, viz Marcus Bingenheimer, ,Some Remarks on the Usage of Renjian Fojiao and the Contribution of Venerable Yinshun to Chinese Buddhist Modernism“, in: Mutsu Hsu - Jinhua Chen - Lori Meeks (eds.), Developement and Practice of Humanitarian Buddhism: Interdisciplinary Perspectives, Hua-lien: Tzuchi University Press 2007, 141-161.

20 Justin R. Ritzinger, ,Taixu: To Renew Buddhism and Save the Modern World“ [online], National Taiwan University Digital Buddhist Library and Museum 2001, <http://enlight.lib.ntu.edu.tw/FULLTEXT/JR-AN/102919.htm>, [24. 8. 2019; 11. 9. 2020 již nedostupné], 74, 90. 
ly. ${ }^{21}$ Yao a Gombrich uvádí, že Taixu následoval tzv. protestantský model: snažil se vymýtit „pověrčivé“ lidové náboženské praktiky, bojoval proti velmi rozšířenému buddhisticko-taoisticko-konfuciánskému synkretismu a po vzoru evropských teologů kladl důraz na systematická a přesná filozofická vyjádření náboženských přesvědčení. Avšak během jeho působení byl buddhismus v Číně minoritním a velmi různorodým náboženstvím bez jakékoliv centrální organizace. Reforma tak byla pro Taixu velmi obtížná. ${ }^{22}$

Zakladatel FGS Hsing Yun, ${ }^{23}$ jeden z nejúspěšnějších žáků Taixu, pokračoval v politice nápodoby křestanství. Měl však naprosto jiné podmínky než jeho učitel. Demokratizace a s ní nově vzniklá nábožensky pluralitní situace na Tchaj-wanu (od roku 1989) mu umožnila získat byrokratickou kontrolu nad svým hnutím a s místní sekulární vládou dodnes udržuje skvělé vztahy. ${ }^{24}$ Hsing Yun je nejen duchovním vůdcem, ale také zkušeným popularizátorem, který stále publikuje, píše divadelní hry a organizuje nespočet hudebních a tanečních akcí. Podařilo se mu např́íklad vybudovat „Buddha Memorial Centre“, buddhistický „Disneyland“, který roku 2011 během prvních tř́i dní navštívilo okolo dvou milionu lidí. Velký vliv Hsing Yuna na Tchaj-wanu se potvrdil roku 1999, kdy přesvědčil místní vládu, aby vyhlásila den Buddhových narozenin státním svátkem. ${ }^{25}$ Hsing Yun si oproti svému učiteli vytvořil silný vztah s katolickou církví. Roku 1989 uspořádal na popud Vatikánu první mezinárodní konferenci římskokatolické církve a buddhismu, o rok později navštívil Jana Pavla II. Dobré vztahy si udržuje také s tchajwanským římskokatolickým arcibiskupstvím a ze svého osobního fondu sponzoruje tchajwanskou katolickou univerzitu a nemocnici. ${ }^{26}$

21 Y.-S. Yao - R. Gombrich, „Christianity as Model...“, 208.

22 Ibid., 222.

23 Hsing Yun odešel z Č́ny na Tchaj-wan roku 1949, stejně jako Čankajšek (Jiǎng Jièshî), společně s přibližně dvěma miliony uprchlíků. Podobně jako Taixu se nikdy nenaučil cizí jazyk a ve svém televizním programu, který vznikl roku 1972, využívá titulky v mandarínštině, nebơ mluví vlastním dialektem z rodné provincie Jiangsu (Jiāngsū). Kariéru na Tchaj-wanu započal roku 1954, kdy se stal představeným kláštera v provincii Yilan (Yūlán). V roce 1967 založil FGS, roku 1978 se sešla první organizovaná komunita FGS v Los Angeles, jež později stála u zrodu chrámu Hsi Lai (Xîlái), největšího buddhistického chrámu v Americe, jenž byl dostaven roku 1988. Dodnes se pod dohledem Hsing Yuna nechalo vysvětit přes tři tisíce mnichů, aktivních je jich okolo třinácti set. Laická organizace BLIA (někde také IBPS, International Buddhist Progress Society) spojuje celosvětově odhadem až 6 milionu lidí. Více viz Y.-S. Yao - R. Gombrich, „Christianity as Model...“, 216.

24 Ibid., 223.

25 Ibid., 216.

26 Ibid., 226. 
FGS se ve svých chrámech drží čínských doktrín a praxe čchanu (chán) a buddhismu čisté země. Avšak i tyto dvě základní tradice prošly v humanistickém buddhismu transformací. Praxe čchanové meditace by se podle Hsing Yuna měla přesunout z uzavřených prostorů klášterů (nebot taková meditace je sebestředná a neslučuje se s ideálem bódhisattvy) do každodenních úkonů praktikujícího; hledání čisté země ${ }^{27}$ a její vytváření má probíhat již zde na tomto světě skrze spirituální kultivaci a očištování vnějšího prostředí. $\mathrm{K}$ tomu by měly dopomoci i nové technologie (např. informační) nebo proces politické demokratizace a environmentalismus. ${ }^{28}$ Podle Chandlera dochází v konceptu humanistického buddhismu k sekularizaci spojené s laicizací, kdy se hranice mezi monastickým a laickým životem pomalu rozpouští. Mniši jsou nuceni k obratu k profánnímu světu, kde se mají věnovat charitě a učit laiky, jak do svého běžného života zakomponovat element „svatosti“. Zatímco je mnišský život sekularizován, naopak ten laický je vystaven procesu sakralizace. Podobné snahy neunikly pozornosti ostatních buddhistických komunit; humanistický buddhismus bývá kritizován za podkopávání mnišské etiky a vyhýbání se tradiční praxi. FGS a další v tomto ohledu podobné řády argumentují, že je jednoduché zůstat „čistý“ za zavřenými dveřmi klášterů. Buddhistické etické učení by mělo být přístupné nejen těm, kteří opustili domov (mnichům), ale také laické veřejnosti. Buddhisté, kteří nenásledují humanistický buddhismus, jsou dle jeho zastánců příliš zaujatí pěstováním moudrosti, ale naprosto opomíjejí důležitost akumulace zásluh ve prospěch ostatních skrze pomoc a péči. $^{29}$

Existují i náboženské praktiky, které Hsing Yun vysloveně zavrhuje, například předpovídání budoucnosti. Nesnaží se však věřící odrazovat od praxe lidového náboženství a uctívání místních božstev (i když je dle něj založeno na touze po bohatství, ochraně, dlouhověkosti nebo štěstí), nabádá ale spíše k ideálu oddanosti, oběti, altruismu a schopnosti dávat. $\mathrm{K}$,idolatrii“" se vyjadřuje taktéž pozitivně, až pragmaticky: jde podle něj o praxi, kterou jak katolíci, tak buddhisté často pro svůj náboženský život potřebují. ${ }^{30}$

27 Nauka o čisté zemi má v Číně dlouhou tradici a bývá spojována s mistry, jako byli např́iklad Nágárdžuna nebo Vasubandhu (což zajištuje nauce vznešenou indickou genealogii). Ve zkratce jde o ,jednodušší“ cestu za zrozením v rajské zemi buddhy Amitábhy a následným dosažením probuzení. Toho lze dosáhnout skrze oslavování zmíněného buddhy odříkáváním jeho jména. Více viz Paul Williams, Mahájánový buddhismus: Základy nauky, trans. Michal Synek, Praha: DharmaGaia 2017, 428-444.

28 Stuart Chandler, „Buddhism in China and Taiwan: The Dimensions of Contemporary Chinese Buddhism“, in: Stephen C. Berkwitz (ed.), Buddhism in World Cultures: Comparative Perspectives, Santa Barbara: ABC-CLIO 2006, 169-194: 187-189.

29 Ibid.

30 Y.-S. Yao - R. Gombrich, „Christianity as Model...“, 227-228. 
Zásadním rozměrem hnutí FGS je misijní činnost. Roku 1988 umožnil Hsing Yun jak théravádovým, tak tibetským ženám získat mnišskou ordinaci po vzoru čínského rituálu, čímž do řad FGS přilákal velké množství věřících žen. BLIA by dle Hsing Yuna neměla sloužit pouze čínsko-tchajwanským uprchlíkům, měla by také výrazně přispět $\mathrm{k}$ misijní snaze řádu a novým konverzím. Mnišky by pak měly být stavebními kameny tohoto společenství, organizátorkami a hlavními fundraiserkami. ${ }^{31}$

Zde si lze položit otázku, proč se tomuto řádu tolik daří na cestě internacionalizace a globalizace a jaké koncepty a strategie $\mathrm{k}$ tomu využívá. Této problematice se akademicky věnuje především Stuart Chandler, který ve svých výzkumech mapuje vývoj FGS v Americe, Africe, částečně v Asii a Oceánii. Několik údajů lze v jeho pracích nalézt i o Evropě, udávané lokality a počty chrámů $\mathrm{v}$ evropských zemích se však často neshodují s těmi oficiálními, které v současnosti zveřejňuje FGS. ${ }^{32}$ Jak Chandler píše, Hsing Yun si uvědomuje, že chrámy, které staví FGS mimo Čínu nebo Tchaj-wan, slouží jako „specifické kulturní mosty vedoucí zpět do Číny“. ${ }^{33}$ Ve vizi Hsing Yuna o globalizaci buddhismu se tak propojuje šíření buddhismu (,tradičního“ čínského, transformovaného do podoby humanistického buddhismu) s propagací a šířením čínské kultury. Aby se však podařilo řádu přilákat i místní obyvatelstvo a „Zasadit semínko“ dharmy v původně nebuddhistických zemích, musí být osloveni i jiní lidé než jen imigranti se stejným sociálně kulturním zázemím, jako má samotný řád. Zde vstupují do hry techniky misijní činnosti, kterou hnutí FGS popisuje třemi základními metodami: 1) vzbuzovat sympatie, 2) podněcovat lidskou zvědavost, 3) ukotvovat buddhistické učení a praxi v dané lokalitě. $^{34}$

Mezinárodní sít chrámů FGS početně převyšuje nejen ostatní čínské buddhistické organizace, ale je také nejrozsáhlejší buddhistickou institucí obecně, zastiňující jiné, často nezávislé, lokální skupiny zenu, tibetského buddhismu či vipassanových forem buddhismu. Co se týče složení sanghy, 99 \% členů BLIA tvoří Číňané, ${ }^{35}$ a misijní strategie, které cílí na nové

31 Ibid., 232-233.

32 Chandler uvádí, že se FGS nachází také v České republice, a nezmiňuje chrám ve Vídni. Podle Chandlera je v Evropě 19 chrámů (viz S. Chandler, „Globalizing Chinese Culture...“, 52), zatímco oficiální stránky FGS mluví o 14 místech, Vídeň zmiňují, Českou republiku nikoliv (viz „Fo Guang Shan Monastery Worldwide Web...“). Zde se nabízí otázka, zda chrámy začaly v Evropě během posledních osmnácti let ubývat, nebo Chandler pouze neměl správná čísla. Pravděpodobnější je druhá možnost.

33 S. Chandler, „Globalizing Chinese Culture...“, 59.

34 Ibid.

35 Vhodnější je pracovat s termínem Číňané než Tchaj-wanci, nebot i samotný řád a jeho členové se svojí identitou hlásí k Číně, která je jim kulturní domovinou. Viz ibid., 56. 
členy (i z řad tzv. „Západ’anů‘36), stojí na důrazu na propagaci tradiční čínské kultury. ${ }^{37}$ Vyvstává zde otázka, jak tento přístup působí právě na zmíněné „Západ’any“. Političtí představitelé cizích států přijímají Hsin Yuna a FGS přivětivě (dle Chandlera především díky milionovým investicím organizace do stavby nových chrámů a následnému nárůstu turismu a možnosti politické podpory ze strany čínských minorit daného státu). ${ }^{38}$ Sám Hsin Yun vyhlásil program tzv. lokalizace buddhismu: zvyky, které přišly z Číny, by měly být postupně nahrazeny těmi místními, samozřejmě v souladu s dharmou. Existuje také specifický typ vzdělávání pod hlavičkou Fo Guang University, ${ }^{39}$ která poskytuje často zdarma intenzivní kurzy $\mathrm{v}$ nauce řádu pro zájemce $\mathrm{z}$ nebuddhistických zemí prrímo na půdě Tchajwanu. Ideální je, pokud se takový zájemce posléze nechá ordinovat. Tito novicové však strádají kvůli obtížnosti přivyknout si na čínské zvyky a hodnoty, taktéž cítí, že je jejich čínští bratři neberou vážně. Z asi tuctu Evropanů a Američanů, kteři byli ordinováni do mnišského stavu, zbyli dle Chandlerových výzkumů pouze dva. Laiky, kteří jsou řádem přitahováni, Chandler dělí do dvou skupin: sinofilové a lidé s primárním zájmem o buddhistické učení. První zmínění program lokalizace odmítají, druzí vítají. ${ }^{40}$

$\mathrm{Z}$ výše napsaného je patrné, že koncept humanistického buddhismu je úzce propojen s misijními aktivitami. Abych mohl tyto činnosti, zejména konkrétní techniky a způsoby misie, studovat detailněji, provedl jsem etnografický výzkum v jednom místě působení řádu - vídeňském chrámu FGS - a zevrubnou diskurzivní analýzu textových a vizuálních materiálů, které řád ve Vídni používá.

\section{Vídeňský chrám FGS}

$\mathrm{V}$ této části se budu věnovat analýze propagačních materiálů FGS Vídeň, přičemž mě bude zajímat způsob, jakým je jejich prostřednictvím

36 Termín jsem převzal od mnišky, která se účastnila mého výzkumu - v originále používala výraz „Westerners“ (z rozhovoru s představenou mniškou z 8. 11. 2017).

37 S. Chandler, „Globalizing Chinese Culture...“, 55-56.

38 Ibid., 62.

39 Fo Guang University byla založena Hsing Yunem a funguje od roku 2000. Kromě této instituce založil řád ještě Nan Hua University (Nánhuá Dàxué) na Tchaj-wanu, The University of the West (USA), Nan Tian (Nántiān) Institute v Austrálii a Guan Ming (Guāng míng) College na Filipínách. Dohromady tvoří tyto univerzity konsorcium a vzájemně si uznávají tituly. Dle propagačních materiálů reflektují zmíněné instituce FGS čínskou akademickou tradici již od dob dynastie Sung a Ming (více viz „Fo Guang University: Taiwan's First Traditional Residential College in a Modern Mode“ [online], in: Fo Guang University, <http://website.fgu.edu.tw/en/about/knowledge>, [11. 11. 2018]).

40 S. Chandler, „Globalizing Chinese Culture..."., 65-66. 
chrám prezentován. Dále se zaměřím na interiér budovy a pokusím se vyzdvihnout ty prvky, které shledávám podstatnými v kontextu hledání sebe-prezentačních strategií, jež cílí na potencionální zájemce z řad „Západ’anů“. Také mě zajímá, jaké diskurzivní strategie a technologie konstruují obraz samotné instituce. Na konci této sekce se tedy pokusím identifikovat institucionální aparát a technologie s ním spojené (tzv. mysl a tělo instituce) a zhodnotit, do jaké míry se tyto mocenské strategie potkávají s reálnou praxí komunity v dané lokalitě.

\subsection{Propagační materiály}

Propagační materiály, jež se vztahují k chrámu, zahrnují brožurky vydané v angličtině a němčině pod názvem Walkabout in the Temple / Rundgang durch den Tempel, A Short Guide / Eine kleine Führer ${ }^{41}$ a webové stránky vídeňské „,buňky“ FGS. K tématu misijních aktivit FGS uvádí: „,buddhismus se k misijní činnosti nezavazuje, působí však skrze své učení" - jako alternativa je potenciálním zájemcủm, především těm, kteří ve svém stávajícím životě již nenacházejí smysl, nabízena nenásilně a ,s otevřenou dlaní“" nová filozofie a př́istup k životu. ${ }^{42}$ Ve všech analyzovaných materiálech je čtenáři předkládáno, že je to právě čínská kultura a tradice, která je schopná obohatit západní svět a přinést dnešním lidem nový smysl života. ${ }^{43}$ Nejde tak jen o strategii šíření buddhistických myšlenek a praxe, FGS klade značný důraz i na čínské reálie a zvyky. „Buddhismus, především čínské tradice, je vhodný pro dnešního moderního člověka“" 44 což by se mělo odrážet i v architektuře chrámové budovy ${ }^{45}$ a designu interiéru, který je dle materiálů nasycen technologickými vymoženostmi ve formě rozličného elektronického vybavení (LCD televize, DVD přehrávače, projektory atd.). ${ }^{46} \mathrm{~S}$ chrámem se dle brožur počítá také jako s centrem pro turisty, místem, kde se budou pořádat nejen náboženské, ale i sekulární společenské akce, jako jsou např́klad bankety různých

41 Oba tyto materiály byly vydány pod hlavičkou Fo Guang Shan Temple Vienna, Order of the Austrian Buddhist Society (ÖBR) a jsou dostupné na oficiálních webových stránkách v německé verzi, viz <http://fgsvienna.at/german/index_d.htm>, záložka „über uns“, [21. 11. 2018; 12. 9. 2020 již nedostupné].

42 FGST Vienna, Walkabout in the Temple, Vienna: Order of the Austrian Buddhist Society (ÖBR) 2014, 1.

43 Ibid.

44 FGST Vienna, A Short Guide, Vienna: Order of the Austrian Buddhist Society (ÖBR) 2010, 1.

45 Na rozdíl od chrámů hlavních (např. v USA nebo na Tchaj-wanu), jež imitují vzhledem starověké čínské vzory, je architektura chrámu FGS Vídeň přizpůsobená na zakázku řádu tomu, aby vyhovovala potřebám moderní společnosti; viz FGST Vienna, A Short Guide..., 1.

46 Ibid., 2; FGST Vienna, Walkabout in the Temple..., 1. 
společností a firem - vídeňská instituce FGS se pro tyto aktivity ve svých propagačních materiálech cíleně nabízí. ${ }^{47}$ Vyzdvihovány a dle materiálů i aktivně podporovány jsou koncepty vegetariánství, meditace, jógy. Potenciálním zájemcům je v materiálech představena základní buddhistická symbolika, která je v chrámu všudypř́ítomná ve formě kaligrafií, soch, obrazů a rituálních předmětů. Obě brožury obsahují vždy alespoň částečné představení základní buddhistické nauky a zvykủ.

Akcent na ekonomiku darů a soběstačnost chrámu je $\mathrm{v}$ analyzovaných materiálech značný; v brožurách je upozorňováno na to, že veškeré výdaje související s topením, elektřinou či opravami jsou kryty výhradně z donací. ${ }^{48}$ Taktéž jsou evidentní výše popsané „lokalizační“ snahy, viditelné např́klad v návodu, jak se chovat k mnišce: „Obvykle se mniškám ruka nepodává, avšak protože je $\mathrm{v}$ naší (západní) kultuře považováno podání ruky za zdvořilé, máte možnost tak učinit. ${ }^{49}$ Tuto ochotu ,jít naproti““ můžeme také spatřovat v konstatování, že návštěvník by díky překladům z čínštiny do němčiny měl veškerým nápisům, kaligrafiím a panelům rozumět - chrám je tedy na něj připraven. Zajímavostí je, že nejen v těchto materiálech, ale i v dalších, které se věnují symbolice FGS nebo buddhistické ikonografii obecně, je kladen velký důraz na vysvětlení rozdílu mezi nacistickým hákovým kř́žem a buddhistickou svastikou. ${ }^{50}$ Obava ze záměny symbolů a možné dezinterpretace je očividná, tím spíše v německy mluvících zemích. ${ }^{51}$

\subsection{Interiér chrámu}

Chrám je po celý den zamčený a po zazvonění otevře většinou představená mniška. ${ }^{52} \mathrm{~V}$ recepci čeká na návštěvníky mnoho nástěnek a propagačních materiálů, většina je pouze v čínštině. Snaha řádu vyjadřovat se

47 FGST Vienna, A Short Guide..., 2.

48 Ibid., 1; FGST Vienna, Walkabout in the Temple..., 2.

49 FGST Vienna, A Short Guide..., 1.

50 FGST Vienna, Walkabout in the Temple..., 2.

51 FGS se této problematice věnuje především v publikaci Encyklopedie pro praktikujicí buddhisty. Zde se uvádí, že symbol svastiky začal být využíván společně s dharmačakrou (kolem dharmy) jako reprezentativní znak buddhismu již ve starověku. Němečtí nacisté však použili svastiku ve svém logu politické strany - obecně je tedy dnes znám především jako symbol boje. Dále je v textu upozorňováno na rozdílný sklon nacistického symbolu a svastiky a také na to, že buddhistické skupiny v Německu se dodnes snaží zobrazení vyhýbat. Dle svérázného výkladu encyklopedie FGS se nacisté skrze nápodobu tohoto symbolu pokoušeli vyvolat falešný dojem mírových záměrů, a tím i maskovat skutečné válečné činy; viz Chuang Tzu, Faxiang: A Buddhist Practitioner's Encyclopedia, Los Angeles: Buddha's Light Publishing 2012, 333.

52 Prezentované informace vycházejí z mých pozorování, terénních poznámek a vlastních fotografií. 
k aktuálním společenským tématům je zjevná z velkého souboru brožur, které se zabývají uměním, ale i například problémem zachování životního prostředí nebo ženskými právy. Místnost je vyzdobena malbami a kaligrafiemi, ty mají často čínské, anglické a německé vysvětlení.

Hned na dohled od vchodu se nachází místní knihovna, prostorná místnost s barem a tzv. „Dharma-shopem“. Řád FGS zde distribuuje všemožné přivěsky, sošky a korálky, hudbu a DVD nosiče, vonné tyčinky, termosky, čajové komplety, misky nebo jídelní hůlky. Jen osm z šedesáti polic knihovny zabírá překladová literatura (zbytek je čínsky), tyto publikace tematicky cílí na všechny věkové skupiny a zaobírají se snad každým aspektem života a filozofie, samozřejmě v interpretacích FGS. K nalezení jsou v knihovně životopisy Buddhy (i ve formě komiksu; nalezl jsem také jeden komiks o Mistru Hsing Yunovi, který ho biograficky zobrazuje jako super-hrdinného mnicha ${ }^{53}$ ), dále knihy o historii, slovníky, návody k rituálům, správné výchově, výklady k Lotosové sútře, Diamantové sútře atp. FGS nezapomíná ani na nejmladší, například Little Panka Sweeps His Mind ${ }^{54}$ kniha určená pro děti od 3 do 8 let, popisuje životní příběh malého novice a jeho strádání při snaze přizpůsobit se životu v klášteře. Dětem od 6 do 9 let je zase věnována publikace s názvem Little Lotus and the Loving-Kindness Cup ${ }^{55}$ určená pro „,malé bódhisattvy“. Převážná většina knih se ale soustředí na fillozofii humanistického buddhismu, meditaci, moudrost a podobné koncepty, včetně praktických návodů na život (a smrt). Vydavatelství BLP (Buddha's Light Publishing) taktéž vydává příručky, které by měly pomoci případným zájemcům $\mathrm{v}$ orientaci v ikonografii nebo náboženských artefaktech. Např́iklad kniha Bells, Gongs and Wooden Fish, ${ }^{56}$ původně vydaná již roku 1953, kombinuje popis artefaktů, jako jsou mnišská roucha, boty, mály či meditační hole, ${ }^{57}$ s lyricko-satirickými statěmi kritizujícími stav čínského buddhismu v první polovině 20. století. Snad všechny publikace byly vydány po roce 2000 a mají

53 Zheng Wen, Star and Cloud: The Biography of Venerable Master Hsing Yun, Hacienda Heights: Buddha's Light Publishing 2003.

54 Fa Ze, Little Panka Sweeps His Mind, Los Angeles: Buddhas Light Publishing 2013.

55 Susan Tidwell, Little Lotus and the Loving-Kindness Cup, Hacienda Heights: Buddha's Light Publishing 2012.

56 Hsing Yun, Bells, Gongs and Wooden Fish, Los Angeles: Buddha's Light Publishing 2012.

57 Mála je náramek či náhrdelník, na kterém jsou ve specifickém počtu $(108,54,42,21)$ umístěny korálky z různého materiálu (semínka, santalové dřevo, drahé kameny apod.). Slouží k počítání manter, využívá se při recitaci buddhistických textů, opakování specifického buddhova jména atd. Meditační hůl je opracované dřevěné „,pádlo“ ve tvaru meče, které se využívá k umravňování praktikujících. Existuje více typů, například „zákonná hůl“" slouží k trestání prohřešků proti mnišským pravidlům, „hlídací hůl““ zase k napomínání spících nebo jinak roztržitých meditujících. Viz Hsing Yun, Bells, Gongs..., 131. 
určenou cenu v eurech, některé na konci obsahují seznam donorů, seřazených dle počtu dotovaných výtisků. Během výzkumu jsem dostal knihy $\mathrm{k}$ dispozici, některé mi byly dány darem, jiné jsem zaplatil. Obecně jsem vypozoroval, že je řád otevřený akademikům a s badateli spolupracuje. Jak mi sdělila mniška, čím více se bude o FGS psát, tím lépe. ${ }^{58}$

V prostředním patře chrámu se nachází moderně zařízená hlavní svatyně a pamětní síň. Do ní vede úzký průchod a působí relativně uzavřeně, uvnitř hraje magnetofonová smyčka s mantrami, doprovázená rytmickým klepáním perkusního nástroje. Napočítal jsem zde kolem šesti set památečních destiček, kdy za každou z nich musel zájemce zaplatit řádu relativně vysoký obnos peněz (dle informací jednoho z členů FGS více než $1000 €) .{ }^{59} \mathrm{Na}$ památečních destičkách se tak dá také dobře vypozorovat vysoké sociální postavení té či oné rodiny. Podobný jev jsem zaznamenal také v hlavní svatyni, která byla v době mého výzkumu připravena na tzv. Zeremonie des Medizinbuddhas. ${ }^{60}$ Před hlavní oltářní sochou se nacházely kaskády se skleněnými soškami buddhů, které měly pod sebou čínské jmenovky. Opět šlo o zobrazení hierarchie donorů: nahoře, pod největšími a nejviditelnějšími soškami, byla jména těch, kteří darovali největší sumu, dole, na téměř neviditelném místě, byli zas ti, kteři si nemohli podobně štědrý dar dovolit.

Třetí patro s meditační halou bylo po většinu času zamčené - jak uvedla mniška, důvodem je lepší přehled o příchozích. ${ }^{61}$ Místnost má kapacitu asi třicet lidí a prostoru dominuje velká socha Buddhy Šákjamuniho. Dostat se dovnitř bylo možné pouze během hodin jógy; dle mnišky zde žádné kurzy meditace neprobíhají. ${ }^{62}$ Avšak jóga, vedená starším mužem a navštěvovaná výhradně „Západ’any“, začínala meditačním sezením, kdy skupina pracovala s knihou Die 7 Minuten-Buddha-Meditation (jež ale nebyla vydána vydavatelstvím FGS). Z následného rozhovoru s představenou chrámu vyplynulo, že zmíněnou knihu zná v čínském provedení, o meditacích skupiny však nevěděla, a jak uvedla, je „možné, že někteří z nich praktikují“63

Pod celým komplexem chrámu, který má bezbariérový přístup a výtah, se nachází nákladně vybavená kuchyně (s vlastním skladem a chladicí místností) a jídelna, která také občas slouží jako přednáškový sál. Na

$58 \mathrm{Z}$ rozhovoru s představenou mniškou z 8. 11. 2017.

59 Z rozhovoru s Ernstem ze 17. 11. 2017.

60 Tyto oslavy, na které jsem byl pozván představenou mniškou, probíhaly mezi 18 . a 19. 11. 2017. Většina modliteb, manter a prostrací směrovala k tzv. Buddhovi hojiteli, jenž je v textech FGS líčen jako populární postava mahájánového buddhismu, která léčí nemocné na těle i duchu (viz Man Chien, Entry into the Profound..., 88).

$61 \mathrm{Z}$ rozhovoru s představenou mniškou z 11. 11. 2017.

62 Ibid.

63 Ibid. 
zdech visí mnoho hesel v německém jazyce, například „Pokud pochopíte Patero rozjímání, dokážete i zlato strávit“64 nebo „Pravidla jsou základem pro nejvyšší probuzení“. $K$ hostině se zde může sejít i přes sto lidí, místnosti vévodí oltář s postavou „,smějícího se buddhy““ 65

\subsection{Mysl a tělo chrámu ve Vídni: Institucionální aparát a související technologie}

Po představení propagačních materiálů a chrámového interiéru se pokusím určit, jaká jsou klíčová témata, respektive mocenské/pravdivostní nároky, které jsou návštěvníkům skrze propagační diskurz instituce předkládány, a jaké technologie tento diskurz materializují a podporují v každodenním běhu chrámu. Prostřednictvím budovy, jež je díky svému designu zároveň místem pro meditaci, ceremonie, vzdělání i umění a volný čas, nabízí řád FGS vídeňským obyvatelům specifické centrum, které by mělo přilákat a propojit zájemce o čínskou kulturu a buddhismus s důrazem na učení čchanu a čisté země. Místo má ,zušlechtovat“ lidského ducha, je vybaveno pro potřeby nejen náboženské, ale i sekulární povahy, vše pod hlavičkou doktríny humanistického buddhismu. Instituce počítá se dvěma typy návštěvníků: lidmi se stejným nebo podobným sociokulturním zázemím (tedy vesměs buddhisty čínského původu), kteří by se v chrámu měli cítit jako doma, a s potencionálními zájemci z řad „Západ’anů“, kteří zavítají ze zvědavosti. Ta by měla být umocněna koncepty, které řád shledává $\mathrm{z}$ hlediska sebeprezentace atraktivními: modernita a otevřenost, vegetariánství, environmentalismus, humanismus a sociální angažovanost, umění. Domnívám se, že akcentace čínské kultury, buddhistických myšlenek a zmíněných konceptů zde funguje jako specifický mocenský nástroj, který má za cíl představit příchozím nový způsob života (nebo potvrdit ten stávající) a vést, organizovat a kontrolovat návštěvníky (jak z řad stálých členů, tak nových zájemců). Jde tedy o formu sociálního managementu. ${ }^{66}$

64 V originále „Wenn ihr Fünf Betrachtungen versteht, konnt ihn sogar Gold verdauen“. Patero rozjímání odkazuje k praxi vedení myšlenek, která by měla být provozována během jídla. Více viz Chuang Tzu, Faxiang..., 179-180.

$65 \mathrm{~K}$ tomuto zobrazení najdeme v textech FGS komentář, že jde o postavu Maitréji (čínsky Mi Lo Fo), bódhisattvy s velkým břichem a budoucího buddhy, jehož podoba vznikla za čínské dynastie Sung (960-1278). Obezita symbolizuje prosperitu, nebot ve stř̌edověké Číně si mohl dovolit být obézní pouze bohatý člověk. Sochy Mi Lo Fo jsou často umistovány právě do jídelen. Viz Man Chien, Entry into the Profound..., 24.

66 Argument, že mocenská síla muzeí a galerií spočívá ve velmi podobném využívání „kultury“ jako prostředku k sociálnímu managementu, přináší již Bennet, viz např. Tony Bennet, The Birth of the Museum: History, Theory, Politics, London: Routledge 1995, 6 . 
Institucionální moc je artikulována a materializována technologiemi, jako je například organizace prostoru chrámu, která umožnuje kvalitnější disciplinární dohled nad děním v celé budově. Jednotlivá patra jsou rozdělena dle funkce. V prvním probíhá vzdělávání a administrativa, druhé slouží jako svatyně, třetí je místem pro meditaci či jógu. Podzemní část funguje jako místo pro společenské události (společné stravování, přednášky apod.). S kontrolou aktivit v chrámu souvisejí i moderní audiovizuální technologie, které zajištují možnost sledování či poslechu totožné produkce ve stejný čas v celém komplexu. Kamerový systém je také přítomen.

$\mathrm{S}$ artefakty $\mathrm{v}$ interiéru (sochami, kaligrafiemi či jinými zobrazeními s buddhistickou tematikou) je zacházeno nejen jako s předměty rituálními, ale poukazuje se také na jejich uměleckou hodnotu; ikonografický popis u každého objektu zároveň slouží jako prostředek $\mathrm{k}$ představení dalších detailů doktrín FGS. Určité prostory či ,instalace“ jsou designovány tak, aby upozornily na rozdíly $\mathrm{v}$ ekonomickém kapitálu různých členů nebo celých rodin (viz zmíněná pamětní síň nebo cedule u vchodu do hlavní svatyně se jmény donorů, kde platí pravidlo „čím větší dar, tím větší font“"). Skrze textové materiály je řádem oslovováno co největší možné spektrum čtenářù a obtížně se nalézá společenské téma, které by v nějaké publikaci nebylo zmíněno a vysvětleno optikou organizace FGS.

Co se týče architektury, budova byla navržena na míru potřebám FGS vídeňským architektem; buddhistická symbolika je vtisknuta do samotného tvaru budovy. Okna jsou velká a světelná, do celého chrámu je možné vidět ze dvou přiléhajících ulic, a tudíž je interiér kolemjdoucím přístupný pouhým pohledem. Instituce si jak skrze textové, tak vizuální technologie vytváří vlastního „diváka“. Je mu říkáno, jak se má chovat (jak uvnitř chrámu, tak k mnišce), jisté nápisy nebo umístění předmětů mu jasně naznačí, kde se smí nebo nesmí v objektu pohybovat a které místnosti jsou důležitější než jiné. Kontrola příchozích neprobíhá jen skrze vždy přítomnou mnišku, i ostatní členové organizace dohlížejí na chod chrámu a chování lidí v něm.

Tato mikrofyzika mocenské strategie, spojující aparát a technologie, však musí být uvedena do praxe, a aby byla úspěšná, jednání „,správce“ a komunity chrámu by mělo se snahou FGS korespondovat. V př́ípadě vídeňského chrámu jsem během terénního výzkumu zjistil jisté disharmonie. Nesoulad s prezentovanými informacemi $v$ propagačních materiálech je možné spatřit již na webových stránkách FGS Vídeň, kde je zřetelná informační nevyrovnanost mezi německou a čínskou verzí stránek. Jisté informace německá verze vůbec neobsahuje, zveřejňované plakáty jsou pro 
zájemce neznalé čínštiny jen velmi těžko srozumitelné. ${ }^{67}$ Při vstupu do chrámu se tato diskrepance pouze zvětšuje, nástěnky a plakáty jsou čínské, některé kaligrafie nejsou přeloženy nebo vysvětleny, to samé platí i pro knihovnu, v níž je drtivá většina knih v čínštině. Již zmíněný fakt, že chrám je po celý den zamčený, rolety zatažené a některé místnosti návštěvníkům uzavřené, strategii otevřenosti taktéž nepomáhá. Na tento fenomén upozorňovali i participanti výzkumu, kteří taktéž uváděli, že dřive byla u vchodu cedule s nápisem „Všichni jsou srdečně vítáni!“. Po příchodu nové mnišky ${ }^{68}$ cedule zmizela, vchod se začal zamykat, rolety se zatáhly. ${ }^{69}$ Důležitým aspektem disfunkce misijních strategií je také omezení mnohých aktivit, které jsou propagačními materiály prezentovány: lekce meditací byly zrušeny, jóga není vedena řádem (pouze je poskytován prostor), kurzy čínštiny či tchaj-tii (tàijí) neexistují. Tyto a další problémy, které souvisejí s vedením chrámu a komunitou, jsou zevrubněji rozebrány v následující sekci.

\section{Komunita chrámu FGS Vídeň}

Pro dotvoření celistvého obrazu živé instituce FGS ve Vídni je neméně důležité zmapovat komunitu členů. Na základě dat získaných zúčastněným pozorováním a rozhovory jsou $\mathrm{v}$ této části studie představeny aktivity, které se v prostoru chrámu odehrávají, posléze je věnována pozornost roli a vlivu mnišky na život $\mathrm{v}$ chrámu a náboženské materiální kultuře západních členů, kteří se dodnes $\mathrm{v}$ komunitě pohybují. V závěru této sekce se soustředím na okolnosti, jež dle mých informátorů podporují, nebo naopak znesnadňují sociální integraci minority „Západ’anů“, taktéž mě zajímá jejich reflexe vnitřních mocenských struktur řádu a účinnosti sebe-prezentačních a misijních strategií.

67 Stránky byly v době výzkumu dostupné na <http://www.fgsvienna.at/>, [24. 11. 2018]. Dnes má web FGS Vídeň již jinou podobu; k této problematice se vyjadřuji v závěru.

68 Politika FGS ve věci představených chrámů spočívá v tom, že každé čtyři roky dochází $\mathrm{k}$ cirkulaci mnichů/mnišek, aby se zabránilo př́lišné připoutanosti představeného k dané komunitě. Do evropských chrámů jsou dosazovány převážně ženy, nebot dle hlavního centra FGS na Tchaj-wanu, kam se jezdí každá mniška či mnich jednou ročně vzdělávat, jsou ženy pro Evropany (ale i pro Američany a Australany) daleko př́istupnější a důvěryhodnější než muži (z rozhovoru s představenou mniškou z 9. 11. 2017; stejné informace jsem získal i od Ernsta v rozhovoru ze 17. 11. 2017).

$69 \mathrm{Z}$ rozhovoru s Hansem z 16. 11. 2017. 


\subsection{Aktivity}

Během každotýdenních nedělních ceremonií se v chrámu pohybuje okolo čtyřiceti až sedmdesáti věřících, v posledních čtyřech letech (2013-2017) ale navštěvoval tyto akce pravidelně jen jeden člověk s původem v jiném kulturním zázemí, než má čínská majorita. ${ }^{70}$ Komunita chrámu je složena převážně z žen, mnohé jsou starší padesáti let. Mezi sebou mluví výhradně čínsky a jen několik jedinců ovládá němčinu nebo jiný světový jazyk. Ti bývají využíváni pro tlumočení návštěvníkům ceremonií (které probíhají výhradně v čínštině), průvodcování nebo prostř̌edkování mezi řádem a rakouskými úřady. Řadoví členové mohou (ale nemusí) během obřadů využívat černý oděv (který je objednán a dovezen z hlavního centra FGS na Tchaj-wanu), pokročilejší laici oblékají navíc úbor hnědý. ${ }^{71}$

Běžné nedělní ceremonie trvají okolo hodiny a půl, skládají se ze čtení súter (které jsou každý týden obměňovány), invokací jmen buddhů (převážně Amitábhy) a společného zpěvu manter během koordinované chůze prostorem hlavní svatyně. Na konci pronáší mniška krátkou řeč, která souvisí s humanistickým buddhismem a každodenním náboženským životem. Každý participant obřadu má $\mathrm{k}$ dispozici skripta $\mathrm{v}$ čínštině, stolek (jednotlivé stolky jsou ve svatyni uspořádány do řad) a sedátko/klekátko. Pokud přijde návštěvník, který nerozumí čínsky, je mu dodán text s přepisem čínštiny do pinyinu, někdy i s anglickým či německým překladem a přiřazen „,dozorce“, který dohlíží, aby dotyčný držel krok s velmi rychlou recitací a neztrácel se v textu. Během krátké rozmluvy mnišky se dozorce vystř́íá s překladatelem, který se snaží šeptem tlumočit čínský projev představené. Občas jsou také rozdána sluchátka s malými rádii a návštěvník je odkázán na vhodnou frekvenci, na níž může poslouchat německý nebo anglický simultánní překlad, většinou podle toho, jaký překladatel a s jakými jazykovými schopnostmi je v chrámu přítomen. Z mé zkušenosti a také z rozhovorů s dalšími ,západními“ účastníky ceremonií (většinou jednorázovými hosty) však vyplývá, že i přes veškeré snahy „místních“ je opravdu obtížné jakkoliv se držet recitací a neztrácet se v textu, natož mu rozumět. Problémem také bývá množství fyzických úkonů (klekání, vstávání, prostrací), které znemožňují udržet oční kontakt s hustě psaným textem súter či dalších náboženských textů. ${ }^{72}$

Oslavy svátků bývají spojeny s většími ceremoniemi, které trvají celý víkend. Například obřady pořádané na oslavu Bhaišadžjagurubuddhy (Zeremonie des Medizinbuddhas) se odehrávaly dva dny, vždy od devíti

$70 \mathrm{Z}$ rozhovoru s představenou mniškou z 29. 11. 2017.

71 Z rozhovoru s Ernstem a Friedrichem z 12. 11. 2017.

72 Tyto poznatky vycházejí z terénních poznámek a spontánních rozhovorů z běžných nedělních ceremonií, na kterých jsem byl přítomen (5. 11., 12. 11., 26. 11. 2017). 
hodin ráno do půl šesté večer. Př́itomní čínští buddhisté mi vysvětlili, že první den oslav je věnovaný očistě vlastní karmy a těla, druhý den je zaměřen na individuální pokání a vyjádření lítosti. Psychická i fyzická náročnost těchto akcí, především pro neznalého návštěvníka, je opravdu značná. Chrám FGS poskytuje po každé ceremonii vegetariánskou hostinu, která se odehrává v dolních prostorech chrámu. Zde se občas objevili i „Západ’ané“, kteří se ceremonií neúčastnili. Jak mi vysvětlil jeden z informátorů, šlo o ,př̌iženěné a přivdané“ rodinné příslušníky čínských rodin, kteří se kromě hostin v komunitním životě neangažuji. ${ }^{73}$

Kromě ceremonií se v prostoru chrámu organizují již zmíněné lekce jógy, které jsou však bez vedení či jakékoliv kontroly zdejší komunitou. Dochází sem lidé, kteří nejsou členy FGS ani se neúčastní řádových akcí, pouze za poplatek využívají nabízený prostor. Další společenskou aktivitou jsou setkání „orchestru mladých“ (Vienna FGS Youth Orchestra). Mladí hudebníci z Vídně (mnohých národností a vyznání), kteří byli vybráni konkurzem, mají v prostorech chrámu pravidelné zkoušky každý týden. V chrámu je jim umožněno nacvičovat pod podmínkou, že posléze odehrají sérii koncertů např́íč Asií, které financuje a organizuje BLIA. ${ }^{74}$ Lekce humanistického buddhismu probíhají údajně velmi sporadicky a pouze v čínštině. Dle Hanse (jednoho z hlavních informátorů) existovaly v chrámu meditační dny, avšak po příchodu tehdejší mnišky byly zastaveny a meditační hodiny přešly pod jeho správu. Hans vedl kurzy se svolením představené (což hodnotí jako pozoruhodné, nebot není běžné, aby mnich svěřil meditační vedení do rukou „Západ’ana“), na jeho kurzy ovšem nedocházeli žádní Číňané. Tuto okolnost Hans vysvětlil tím, že „místní nemají o meditace zájem, pouze navštěvují ceremonie. Náboženskou praxí je pro ně jen recitace manter, invokace a dovolávání se pomoci Amitábhy a dalších buddhů a bódhisattvư “" ${ }^{75}$ Hans vedl meditace do té doby, než si otevřel vlastní meditační halu a celá třída se pak společně s ním přesunula mimo chrám. ${ }^{76}$

\subsection{Mniška a ,Západ’ané“6}

Mniška, která v době výzkumu spravovala chrám, pochází původně z Malajsie (z druhé generace čínských imigrantů) a ve Vídni pracuje čtyřri roky. Od svých 28 let je ordinována (dnes je jí kolem padesáti) a ve službě FGS v Evropě je již od roku 1992. Prošla si komunitami v Londýně, Manchesteru a Ženevě. Uvádí, že sangha ve Vídni čítá kolem pěti set

73 Z terénních poznámek a rozhovoru s Friedrichem (18. a 19. 11. 2017).

$74 \mathrm{Z}$ rozhovoru s představenou mniškou z 29. 11. 2017.

75 Z rozhovoru s Hansem z 22. 11. 2017.

76 Ibid. 
členů, z nichž pouze tři jsou nečínského původu. Z těchto tř̌i dochází pravidelně na ceremonie jeden. $\mathrm{V}$ komunitě se podle mnišky propojili nejen rakouští imigranti s konfuciánským či buddhistickým zázemím, ale začalo docházet také mnoho taoistů, kteři si prostředí chrámu oblíbili. Příčinu toho, že je v komunitě tak málo „Západ’anư“, spatřuje mniška v nátuře a způsobu života Evropanů, kteří jsou nestálí a více se pohybují za prací nebo studiem. Problém vidí také v kulturních rozdílech a krátkém čase působnosti FGS v Evropě. Představená dále tvrdí, že třídy meditace nebo překladatele na lekce humanistického buddhismu by byla schopna obstarat, není však o ně zájem. Na ceremonie dochází pouze Číňané, není tedy důvod promlouvat $\mathrm{v}$ jiném jazyce. Zmiňuje nezájem čínské majority o meditace; čínští členové podle ní nemají čas na „náboženství“ a prioritou je pro ně práce. Pokud si čas najdou, chtějí se společně setkávat a být v komunitě jim kulturně a názorově blízké. ,Západ’ané“ jsou oproti tomu více individualističtí, hluční, povídaví a zvídaví. ${ }^{77}$

Svoji pozici a vliv v chrámu vnímá mniška naprosto neutrálně. Jak sama uvádí, drží se konceptů humanistického buddhismu, které jsou jí každý rok znovu vštěpovány na Tchaj-wanu. „Víme, co děláme, a děláme to správně, ... moje individualita se zde [v chrámu a ve vlivu na komunitu] neprojevuje," uzavírá mniška. ${ }^{78}$

Všichni dnešní nečínští členové FGS Vídeň mají původně křestanskou výchovu a o buddhismus se začali zajímat kolem patnáctého roku života. ${ }^{79}$ Mísí se u nich dva postoje: zatímco pro Hanse a Friedricha šlo o alternativu ke křestanství, které jim nedávalo odpovědi na duchovní otázky ani každodenní problémy (,zjistil jsem, že Bible nefunguje“) ${ }^{80}$ pro Ernsta šlo o lepší variantu podobného. Vnitřní dialog, který Ernst vedl v kostele s Pannou Marií, přenesl na modlitbu a hovory s bódhisattvou Avalókitéšvarou. ${ }^{81}$ Friedrich je jediným zástupcem minority nečínského původu, který se ztotožnil s náboženským životem v chrámu a pravidelně dochází na ceremonie. Obléká černé roucho (které dostal darem), nosí náramek s motivem Bhaišadžjagurubuddhy, který obdržel na jedné z ceremonií, a doma má vybudovaný oltář po vzoru oltářu FGS. Často nakupuje v „Dharma shopu“ a pravidelně si půjčuje literaturu. Sice uvádí, že se cítí

$77 \mathrm{Z}$ rozhovoru s představenou mniškou z 29. 11. 2017.

78 Ibid.

79 Z rozhovorů s Hansem (22. 11. 2017), Friedrichem (23. 11. 2017) a Ernstem (17. 11. 2017).

$80 \mathrm{Z}$ rozhovoru s Hansem z 22. 11. 2017.

81 Z rozhovoru s Ernstem ze 17. 11. 2017. Avalókitéšvara se v umění Japonska a Číny často zobrazuje s ženskými rysy a velmi se podobá madoně. Nese jméno Guan Yin (Guānyīn) či japonsky Kannon. Více viz Hanz Wolfgang Schumann, Svět buddhistických obrazů: Ikonografická př́ručka buddhismu mahájány a tantrajány, trans. Jan Filipský, Praha: Academia 2008, 80. 
v komunitě stále jako cizinec, má ale skvělé vztahy především s jedním z překladatelů. Doufá, že jednoho dne zapadne do „místní velké rodiny“. Ve svých každodenních rituálech kopíruje ty, které se naučil v chrámu a je za ně FGS vděčný, nebot mu zlepšily život, zklidňují ho a bez nich se necítí sám sebou. Po dvou letech účasti na ceremoniích mu bylo nabídnuto členství v BLIA, získal legitimaci a začal platit příspěvky. Oproti ostatním členům z řad „Západ’anů“ mi však přišel velmi málo informován. O konceptu humanistického buddhismu podle svých slov vůbec nic neví, stejně jako o tom, že se v chrámu nachází kromě svatyně další funkční patro s meditační místností. ${ }^{82}$

Další dva členové vyprávěli odlišný příběh. S FGS Vídeň jsou oba spojení již od počátku působení hnutí, vypomáhali mu například s administrativou během zařizování a stavby nového chrámu. Také se jim podařilo zaregistrovat FGS do unie ÖBR (Österreichische Buddhistische Religionsgesellschaft), která sdružuje oficiálně uznávané rakouské buddhistické organizace. I když byli tito členové zvoleni na určitou dobu do vysokých postů vídeňského výboru BLIA, dnes již do chrámu dochází jen jako dobrovolníci, pokud od nich řád potřebuje výpomoc (komunikace $\mathrm{s}$ úřady, technická údržba chrámu či průvodcovství občasných návštěv školních tř̌id). Jejich vlastní náboženská materiální kultura se v mnohém neshoduje s praxí FGS, o ceremonie nemají zájem, chrám pro ně neslouží jako obřadní místo či místo setkávání s názorově blízkou komunitou. Č́stečně se sice stále hlásí $\mathrm{k}$ čchanové nauce, po určité době si ale oba našli i tradice jiné, které jim vyhovovaly více především $\mathrm{z}$ hlediska praxe. ${ }^{83}$ Důvodů, které je odrazují od většího angažování se v hnutí, je několik. Především uvádějí odklon od ideálů humanistického buddhismu, jeho konceptu otevřenosti a důrazu na charitativní činnost. Komunita se podle Hanse a Ernsta uzavírá vůči vnějšímu světu a zaobírá se více vnitřními kulturními akcemi (ceremonie, pohřby, hostiny), než aby se věnovala činnosti sociální a charitativní. ${ }^{84}$ Tento posun byl podle nich způsoben dvěma faktory: prvním je přístup komunitního výboru FGS Vídeň, který mezi sebe nepouští „Západ’any“, a pokud ano, pouze na dobu, kdy je to nezbytné z hlediska řešení administrativních úkonů. Hans a Ernst reflektovali své zklamání z neúspěšné snahy cokoliv změnit, údajně naráželi stále více na ignoraci ze strany čínské majority. Na výborových setkáních se mluvilo postupem času jen čínsky, ,západní“ členové byli následně vyloučeni z vedení. Na jedné z ceremonií mi Hans smutně pokynul směrem k zasedací

$82 \mathrm{Z}$ rozhovoru s Friedrichem z 23. 11. 2017.

83 Z rozhovorů s Hansem (22. 11., 26. 11. 2017) a Ernstem (17. 11. 2017).

84 Ibid. 
místnosti a řekl: „Podívej... už jsem jen obyčejný člen, támhle už se baví za zavřenými dveřmi beze mě.“ 85

Kritika Hanse a Ernsta ovšem sahala ještě dále. Jako nově příchozí je každý „,adept“ majoritní komunitou údajně sledován se zájmem o to, co může nabídnout (peníze, čas či znalosti), a podle toho je s ním pak nakládáno. Zmíněn byl i jistý druh pasivního nátlaku a kontroly. Pokud má člen požadovaný atribut, bude tolerován, nikdy ale nebude přijat. Ernst svou spolupráci s výborem BLIA reflektoval následovně:

Šest let jsem to dělal. Byla to doba plná zklamání a smutku. Vše bylo samozřejmě neplacené, cítil jsem se jako černá ovce a nepochopen. ... Nejsem jako oni, nejsme přátelé. ${ }^{86}$

Opakovaně také v negativním světle zmiňovali hierarchii v představenstvu FGS, která se odvíjí od ekonomického kapitálu jednotlivých členů (což koresponduje i s výše zmíněnými institucionálními technologiemi, které jsou v praxi uplatňovány v architektuře a výbavě chrámového prosto$\mathrm{ru})$.

Ti, co hodně darují chrámu, budou mít velké jméno na zdi, zatímco ti, co přispějí také, ale jsou chudí, již ne. ... Je to pokrytecké. Do očí vám to neřeknou, funguje zde však očividná hierarchie podle daru, který dáš... to však není od Buddhy, to souvisí $\mathrm{s}$ [čínskou] kulturou. ${ }^{87}$

Dle Hanse a Ernsta je jasně patrná disharmonie mezi chováním FGS Vídeň a koncepty humanistického buddhismu. Oba se shodují, že by se více než na sebeprezentaci mělo hnutí soustředit na sociální pomoc: 88

Nikde nevidím ideu humanistického buddhismu... kde je? ... Peníze nemají jít na luxus a reprezentaci chrámu, ale na humanistický buddhismus, tím myslím charitu. Zdejší [představenstvo BLIA] nehledají do svých řad lidi kompetentní, hledají bohaté. ${ }^{89}$

Druhým faktorem je dle mých informátorů postava mnišky. Panoval mezi nimi názor, že její vedení chrámu zapř́íčinilo úpadek minoritní komunity, která údajně před jejím příchodem tvořila $20 \%$ místní sanghy. ${ }^{90}$ Problémy jsou spatřovány v již zmíněné politice „zamykání a uzavírání se“ $\mathrm{a} v$ přechodu od sociálních aktivit $\mathrm{k}$ aktivitám vnitřně kulturním. Hans dodává:

$85 \mathrm{Z}$ rozhovoru s Hansem během společné hostiny po ceremonii, 26. 11. 2017.

86 Z rozhovoru s Ernstem ze 17. 11. 2017.

87 Ibid.

88 Z rozhovorů s Hansem (22. 11., 26. 11. 2017) a Ernstem (17. 11. 2017).

89 Z rozhovoru s Ernstem ze 17. 11. 2017.

90 Z rozhovoru s Hansem z 16. 11. 2017. 
Někteří lidé zde dokonce čekají, až tato mniška odejde a bude vystř̌idána. Vše se jejím odchodem může změnit. ... Okno do nové kultury a buddhismu se chováním představené zavřelo. ${ }^{91}$

Svůj návrat do chrámu podmiňuje změnou na pozici představené mnišky také Ernst:

Abych se začal vracet do chrámu, muselo by dojít k obrovským změnám. Především to chce novou mnišku a změnu politiky. Otevřenost, liberálnost. Poté si to umím představit. A také více charity, ted' tu žádnou nevidím. ${ }^{92}$

Všichni mí „západní“ informátoři se ale velmi kladně vyjadřovali k vybavení chrámu, architektuře i náladě v laické komunitě místních a přátelskosti a laskavosti běžných členů. Koncept humanistického buddhismu je jim také sympatický (pokud ho znají), myšlenky Hsin Yuna jen údajně nejsou ve Vídni uplatňovány. Z výše zmíněného vyplývá, že aby mohlo dojít k nárůstu minoritní „západní“ komunity, musela by se dle Ernsta, Hanse a Friedricha vystřídat mniška a změnit politika výboru BLIA Vídeň ve prospěch většího důrazu na charitativní činnost a přijímání názorů „Západ’anư“.93 Ernst k tomu dodává:

Mistrovy myšlenky jsou dobré, provedení špatné. Místní [Číňané a mniška] si musí uvědomit, že nejsou v Číně, ale v Rakousku. ... Umí se akorát smát a jíst, ale to nestačí. Musí se naučit, jak vést „Západ’any“, nejen to, jak je nakrmit. ${ }^{94}$

\section{Závěr}

Výsledky této př́ípadové studie se v mnohém potkávají s obecnými závěry na poli výzkumu buddhistických tradic na Západě a procesů sociální integrace buddhistů-imigrantů. Například Baumann uvádí, že požadavky západních „konvertitư“ na náboženský život se v mnohém liší od běžné praxe asijských komunit. Č́ńnané, Thajci nebo Vietnamci navštěvují chrámy sporadicky, a když ano, tak proto, aby skrze rituály nashromáždili zásluhy či se zúčastnili společenských akcí. „Vzdělaná západní mládež“ se podle Baumanna velmi těžko ztotožňuje s tradičními př́istupy asijských učitelů buddhismu a tíhne k aktivnějšímu duchovnímu životu. ${ }^{95}$

$91 \mathrm{Z}$ rozhovoru s Hansem z 22. 11. 2017.

92 Z rozhovoru s Ernstem ze 17. 11. 2017.

93 Z rozhovorů s Hansem (22. 11. 2017), Friedrichem (23. 11. 2017) a Ernstem (17. 11. 2017).

94 Z rozhovoru s Ernstem ze 17. 11. 2017.

95 Martin Baumann, „Buddhims in Europe: Past, Present, Prospects“, in: Charles S. Prebish - Martin Bauman (eds.), Westward Dharma: Buddhims beyond Asia, Berkeley: University of California Press 2002, 85-105: 95-101. 
Organizace Fo Guang Shan ve Vídni volí pro vlastní sebeprezentaci a misii směrem k ,západním“ členům strategie, které jsou postaveny na důmyslném aparátu a technologiích. Ty jsou v očích dotazovaných „Západ’anư “ reflektovány vesměs pozitivně. Design mysli a těla instituce, jež reprezentuje humanistický buddhismus FGS, relativně odráží očekávání těchto zájemců o čínský buddhismus a kulturu.

$\mathrm{V}$ textu jsem poukázal na jisté diskrepance mezi teorií a praxí. Již v prvních provedených analýzách jsem nalezl nesoulad mezi předkládanými koncepty humanistického buddhismu a jejich následnou aplikací v propagačních materiálech vídeňského chrámu. Během terénního výzkumu jsem zjistil, že vztah mezi teoretickými koncepty řádu a konkrétní praxí je antagonický a jeho dynamika je ve velké míre založena na chování místní mnišky a představenstva organizace BLIA. To, že problém nízkého počtu „západních“ členů v sangze FGS Vídeň souvisí s osobou konkrétní mnišky, se dle mého názoru potvrdilo nejen skrze pozorování a výpovědi participantů výzkumu. Během období roku 2018, kdy jsem analyzoval webové stránky této instituce, byly zmíněné diskrepance mezi teorií otevřenosti a praxí naprosto evidentní: německá verze webu ani zdaleka neodpovídala té čínské, byla zanedbávána, nebyla aktualizovaná. Pokud si však otevřeme stránky dnes, je viditelná velká změna: nový design webu, německá verze téměř identická s verzí čínskou, veřejnosti jsou nabízeny lekce jógy a meditace. ${ }^{96}$ Po krátkém pátrání jsem zjistil, že během roku 2019 došlo k výměně mnišky. Domnívám se tedy, že přistup představené chrámu a předsednictva komunity významně ovlivňuje složení sanghy vídeňského FGS, v níž byl v době mého výzkumu pouze jeden aktivně participující člen s jiným než čínským socio-kulturním zázemím a náboženská materiální kultura zbylých dvou členů ,západní minority“ se v mnohém odlišovala od té, kterou propaguje FGS. Z rozhovorů s Hansem a Ernstem pak vyplynulo, že snahy o sociální integraci „západní“ minority selhávaly důvodem byl podle nich zejména fakt, že principy humanistického buddhismu nebyly v každodenním chodu chrámu a aktivitách jeho majoritní komunity dostatečně realizovány.

FGS není v Evropě jediným hnutím, které pracuje s koncepty humanistického buddhismu. Zjištění v této studii, jak se domnívám, tak mohou posloužit jako základ k dalšímu výzkumu a komparacím sebe-prezentačních strategií a jejich úspěšnosti, stejně jako žitého náboženství ,západních" členů v podobných buddhistických organizacích.

$96 \mathrm{Viz}<\mathrm{https}: / /$ www.fgsvienna.at/>, [8. 3. 2020]. 


\section{SUMMARY}

\section{Mind and Body of Humanistic Buddhism in Practice: A Case Study of the Temple and Community of Fo Guang Shan Vienna}

The Fo Guang Shan (FGS) is an international Chinese-Taiwanese Buddhist order, whose special feature is the concept of humanistic Buddhism, through which the order expands and spreads Chinese/Buddhist culture around the world. The aim of this article is twofold. First, it attempts to contribute to the discussion of FGS's efforts to globalize its philosophy and to analyse specific missionary strategies through which the order spreads its doctrine/culture and consolidates its position in originally non-Buddhist countries. Second, it attempts to provide an overview of the specific space (temple) and community of the FGS order in Vienna.

In this text, I argue that the strategies that FGS in Vienna chooses for its self-presentation and to attract members from "Western" socio-cultural backgrounds are based on a well-accepted and sophisticated institutional apparatus and well-designed technologies ("mind and body" of the institution). However, there is a mismatch between the supposed concepts of humanist Buddhism and its application in the propaganda material of the Viennese temple. Furthermore, the relationship between the theoretical concepts underpinning FGS philosophy and the specific practices of the order is of a contradictory nature. The dynamics of this relationship are largely based on the behaviour of local nuns and executives of the community. The results of this study suggest that the disharmony between the philosophy proclaimed by the group and its actual practices could be the main reason that very few members of other socio-cultural backgrounds are attracted to it.

Keywords: Chinese Buddhism; globalization efforts; humanistic Buddhism; Fo Guang Shan; discursive analysis; religious material culture.

Department for the Study of Religions

MARTIN ŠPIRK

Faculty of Arts

Masaryk University

Arna Nováka 1

60200 Brno

Czech Republic 